\title{
PARAMETRIC ASSESSMENT OF LAND CAPABILITY AND SUITABILITY FOR SOME CROPS USING ADVANCED TECHNIQUES.

\author{
Ghabour, T. K. ${ }^{1}$; H. A. Meshref ${ }^{2}$; M. M. Wahba'; Fatma A. Ghali ${ }^{2}$ \\ and Sahar A. Selim ${ }^{1}$ \\ 2- Soil Department, Faculty of Agriculture, El-Mansoura University.
} \\ 1- Soils and Water Use Dept., National Res. Centre, Dokki, Egypt.
}

\begin{abstract}
The current work aims at employing the advanced techniques; GIS and computerized mathematical models for land evaluation, to assess the land capability and suitability of large areas. The area of El-Ismaillia Governorate was chosen as a study area. Sixteen soil profiles, that covered most of the soil types of the area, were selected and characterized. The characterization results were input to ALES-Arid land evaluation software. The outputs revealed that the land capability class C3 (Fair) included most of the soils of the study area where, it covered almost $72 \%$ of the total area under investigation. The soils belonged to land capability C4 (Poor) occupied about $21 \%$ of the entire area of the governorate. These soils had several limitations but severer than those of C3.

The land suitability for the studied crops revealed that most of the soils belong to suitable S1 and moderately suitable S2 for wheat and barely. In the case of maize and rice, however the soils were found to be marginally, conditionally suitable and actually unsuitable. The soils of the region were mostly suitable for alfalfa. Most of the soils in the area were suitable to moderately suitable for sugar beet with few areas of marginally to conditionally suitable. The area belonged to marginally suitable class for sunflower. While the faba-bean showed mostly conditionally suitability in the area.
\end{abstract}

Keywords: Land capability, Land suitability for crops, GIS, ALES.

\section{INTRODUCTION}

The evaluation of soils for agricultural uses on the basis of soil inventories is called soil survey interpretation which can achieve an estimate to what degree a given soil can support a particular farming system.

Land evaluation systems are mostly interpretive classifications relevant to agricultural management and planning. They commonly evaluate the land in various categories; each is corresponding to a certain level of details. The interpretation differs at each level in precision, objective requirements and assumptions, (Ghabour, 1998a).

Land evaluation moves much further in the direction of recommending particular uses of land, (Van Diepen, 1982). Land evaluation systems could define the suitable alternative land utilization types under a particular farming system on a sustained basis.

Land capability classification is considered as a general appraisal however, the preferential utilization type and land use are reflected in its classes. The first FAO Panel for land evaluation held in Wageningen, The Netherlands in 1973 had defined the concept of land utilization types and suggested the classification of land for specific use, (FAO, 1976).

The capability index is an expression of the natural fertility and can, therefore, be correlated with crop production under natural conditions without 
use of fertilizers or implementation of soil improvement works, (Sys et al., 1991).

Geographical Information Systems (GIS) are capable of handling large volumes of spatial data and are designed to efficiently store, retrieve, manipulate, analyze and display these data according to the user defined specifications. Moreover, new data can be generated by combining several existing and/or manipulated information types.

Land suitability classification for crops is an evaluation system for defining the most suitable crop for specific soil. The basic concept of land suitability is to estimate or calculate the matching of the soil properties or qualities and climatic characteristics with the crop requirements.

Sarmadian et al. (2003) employed processing of satellite images and GIS-modeling capabilities for land suitability evaluation in an arid region. They emphasized, in a case study, on the importance and application of spatial and geographical data in land suitability evaluation for soils of an arid region which were classified into Aridisols and Entisosl. Geographical information systems (GIS) and remote sensing techniques were used in this research to produce the necessary maps.

Reddy et al. (2004) characterized the land resources, of eastern Maharashtra plateau and valley areas in India, for cotton suitability using remote sensing and GIS, where the variation in morphological, physical and chemical characteristics was governed by physiography, slope and erosion.

Shekinah et al.(2004), used GIS for land capability evaluation in a part of Sahaspur block of Dehradun district, Uttaranchal, India. The major physiographic units of the area are river terraces, hills, mountains, piedmonts. The soil series of the area belong to four soil orders which are Entisol, Inceptisol, Alfisol and Mollisol and are classified into six major capability classes (II to VIII). Nearly $85 \%$ of the area is found suitable for cultivation and the rest is non-arable. Erosion hazard, topography and soil properties are found to be the major limiting factors.

Ghabour et al. (2006), suggested a numerical approach to land suitability for wheat cultivation in the north-western coast region of Egypt.

Aim of the current study is to employ advanced techniques of GIS and computerized land evaluation method to assess the land capability and suitability of large areas.

\section{Environmental settings of the study area.}

The study area is located at the north east of the Nile Delta, between longitudes $31^{\circ} 45^{\prime} 13^{\prime \prime}$ and $32^{\circ} 27^{\prime} 10^{\prime \prime} \mathrm{E}$ and latitudes $31^{\circ} 07^{\prime} 12^{\prime \prime}$ and $30^{\circ} 12^{\prime}$ $22 " \mathrm{~N}$. It occupies the area of El-Ismaillia Governorate east to Suez Canal, which about $2800 \mathrm{~km} 2$ or almost 666490 fed.

The main irrigation canal in the study area is El-Ismaillia Channel, which is located to south of it, while only a very small northern part of the study area is irrigated from El-Salam Canal. The drainage system includes Bahr El-Baqar Drain which runs through the northern part of the study area, while El-Mahsama and El-Wadi Drains are in the southern part to the south of El-Ismaillia Canal. Even so, a considerable area in the northern part of the study area depends, mainly and for most of the time, on Bahr El-Baqar Drain as a source of irrigation (Fig., 1). 


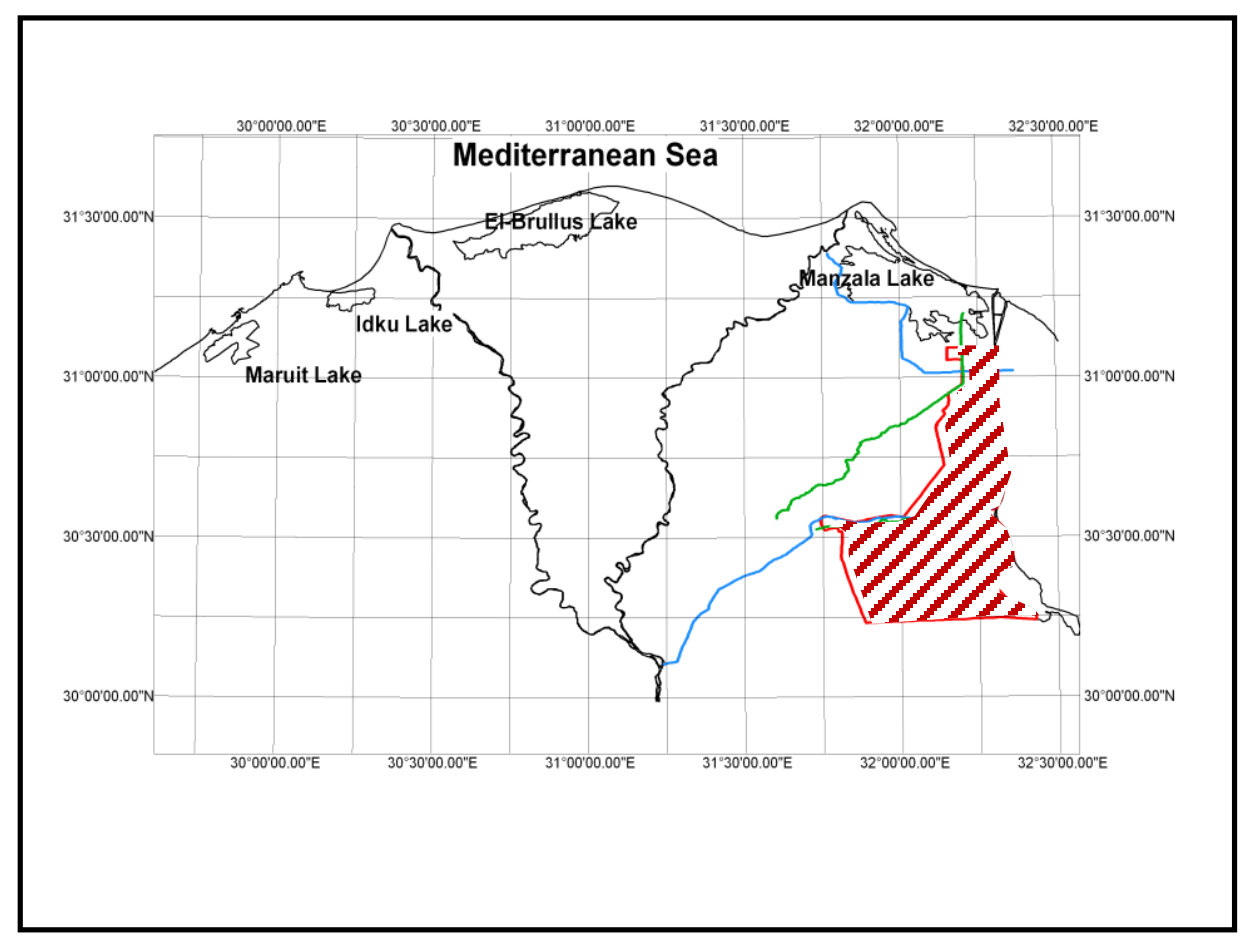

Figure (1): Location Map of the Study Area

The entire territory of El-Ismailia Governorate is located in a zone which could be described as aridic since the evaporation rate, generally, exceeds the precipitation during most time of the year. The main annual temperature is $21.8^{\circ} \mathrm{C}$ with mean annual maximum of $28.8^{\circ} \mathrm{C}$ and mean annual minimum of $14.9^{\circ} \mathrm{C}$. It is characterized by mean annual relative humidity is $51 \%$. The mean annual evaporation rate stands for $4.9 \mathrm{~mm} /$ day, with the mean monthly maximum of $7.8 \mathrm{~mm} /$ day in June and July and mean monthly minimum of $2.4 \mathrm{~mm} /$ day in January. It receives a total amount of rainfall which is determined at approximately $33.3 \mathrm{~mm} / \mathrm{year}$.

The soils of the area were classified into Typic Haplotorrerts, Typic Torriorthents, Typic Torripsamments, Vertic Torrorthents and Gypsic Haplosalids, (Meshref et al, 2008).

\section{MATERIALS AND METHODS}

Sixteen soil profiles were selected in the area, morphologically described following FAO (2006) and sampled for laboratory analyses according to Black et al.(1982) and De Coninck (1978). The averages of the obtained results are presented in table 1. 
Ghabour, T. K. et al.

Table (1): Averages of some soil characteristics per profile

\begin{tabular}{|c|c|c|c|c|c|c|c|c|c|c|}
\hline $\begin{array}{c}\text { Profile } \\
\mathbf{N}^{\circ}\end{array}$ & $\begin{array}{c}\text { Depth } \\
\text { of } \\
\text { profile } \\
\mathbf{( \mathbf { c m } )}\end{array}$ & $\begin{array}{c}\text { Water } \\
\text { table } \\
\mathbf{d e p t h} \\
\mathbf{( \mathbf { c m } )}\end{array}$ & $\mathbf{p H}$ & $\begin{array}{c}\text { ECs } \\
\mathbf{( d S / m )}\end{array}$ & $\begin{array}{c}\mathbf{C E C} \\
\mathbf{m e q} / \mathbf{1 0} \\
\mathbf{0 g} \mathbf{s o i l}\end{array}$ & $\begin{array}{c}\text { ESP } \\
\%\end{array}$ & $\begin{array}{c}\text { Total } \\
\text { carbo } \\
\text { nate\% }\end{array}$ & $\begin{array}{c}\text { Gypsu } \\
\mathbf{m} \%\end{array}$ & $\begin{array}{c}\text { OM } \\
\%\end{array}$ & $\begin{array}{c}\text { Clay } \\
\%\end{array}$ \\
\hline 1 & 60 & 60 & 8.24 & 4.38 & 34.65 & 21.89 & 4.43 & 2.96 & 0.45 & 69.63 \\
\hline 2 & 80 & 80 & 8.49 & 3.76 & 25.70 & 14.60 & 3.18 & 3.35 & 0.28 & 55.24 \\
\hline 3 & 80 & 80 & 7.70 & 62.68 & 36.63 & 31.14 & 2.53 & 23.46 & 0.72 & 63.35 \\
\hline 4 & 80 & 80 & 8.27 & 4.86 & 21.59 & 16.28 & 6.68 & 3.50 & 0.43 & 40.89 \\
\hline 5 & 100 & 100 & 7.78 & 2.20 & 13.99 & 21.20 & 2.26 & 4.24 & 0.65 & 17.84 \\
\hline 6 & 90 & 90 & 8.19 & 2.53 & 9.03 & 27.99 & 3.74 & 2.18 & 0.20 & 12.18 \\
\hline 7 & 110 & 110 & 8.43 & 2.09 & 6.22 & 32.55 & 2.99 & 1.19 & 0.42 & 12.51 \\
\hline 8 & 120 & 120 & 8.32 & 2.06 & 7.26 & 22.78 & 2.83 & 2.00 & 0.36 & 9.73 \\
\hline 9 & 110 & 110 & 8.17 & 2.49 & 8.30 & 19.54 & 2.64 & 2.90 & 0.10 & 8.82 \\
\hline 10 & 120 & 120 & 7.87 & 0.84 & 10.91 & 20.04 & 4.29 & 0.71 & 0.16 & 10.14 \\
\hline 11 & 100 & 100 & 7.61 & 3.18 & 19.36 & 19.50 & 3.91 & 2.42 & 0.28 & 39.70 \\
\hline 12 & 80 & 80 & 7.99 & 1.90 & 22.64 & 18.64 & 3.84 & 1.79 & 0.33 & 32.28 \\
\hline 13 & 120 & 120 & 8.03 & 1.14 & 11.52 & 14.16 & 3.51 & 1.07 & 0.37 & 21.12 \\
\hline 14 & 80 & 80 & 8.03 & 2.17 & 32.05 & 14.94 & 3.81 & 1.08 & 0.82 & 51.61 \\
\hline 15 & 120 & 120 & 7.45 & 2.62 & 8.03 & 22.16 & 5.02 & 1.22 & 0.05 & 4.80 \\
\hline 16 & 120 & 120 & 8.03 & 1.39 & 6.43 & 26.34 & 2.90 & 1.09 & 0.01 & 9.75 \\
\hline
\end{tabular}

Based on the soil physical, chemical and fertility properties as well as climatic data, land capability index was calculated using Agriculture Land Evaluation System (ALES-Arid) as an indicator of land quality. Land suitability index was also carried out to reflect optimum land use by matching standard crop requirements (wheat, barely, maize, rice, alfalfa, faba-bean, sunflower and sugar beet) with land qualities.

The outputs of the land suitability software were input in GIS environment to produce the land capability and suitability maps based on the soil map of the area.

\section{RESULTS AND DISCUSSION}

Land Capability Classification

The soils of El-Ismaillia Governorate had been identified as arable land but classified into two capability classes namely, class 3 (C3) which is described as fair and class 4 (C4) that is described as poor, (Fig.2). The produced map showed the spatial distribution of the capability classes of the study area and their areal coverage were calculated (Table. 2).

Table (2): Coverage area of the Land Capability Classes

\begin{tabular}{|c|c|c|c|}
\hline capability class & $\mathbf{k m}^{2}$ & fed. & \%of the total area \\
\hline C3 & 2018.89 & 480689.27 & 72 \\
\hline C4 & 585.03 & 139292.44 & 21 \\
\hline Rocky area & 195.34 & 46508.71 & 7 \\
\hline Total area & 2799.26 & 666490.42 & 100 \\
\hline
\end{tabular}




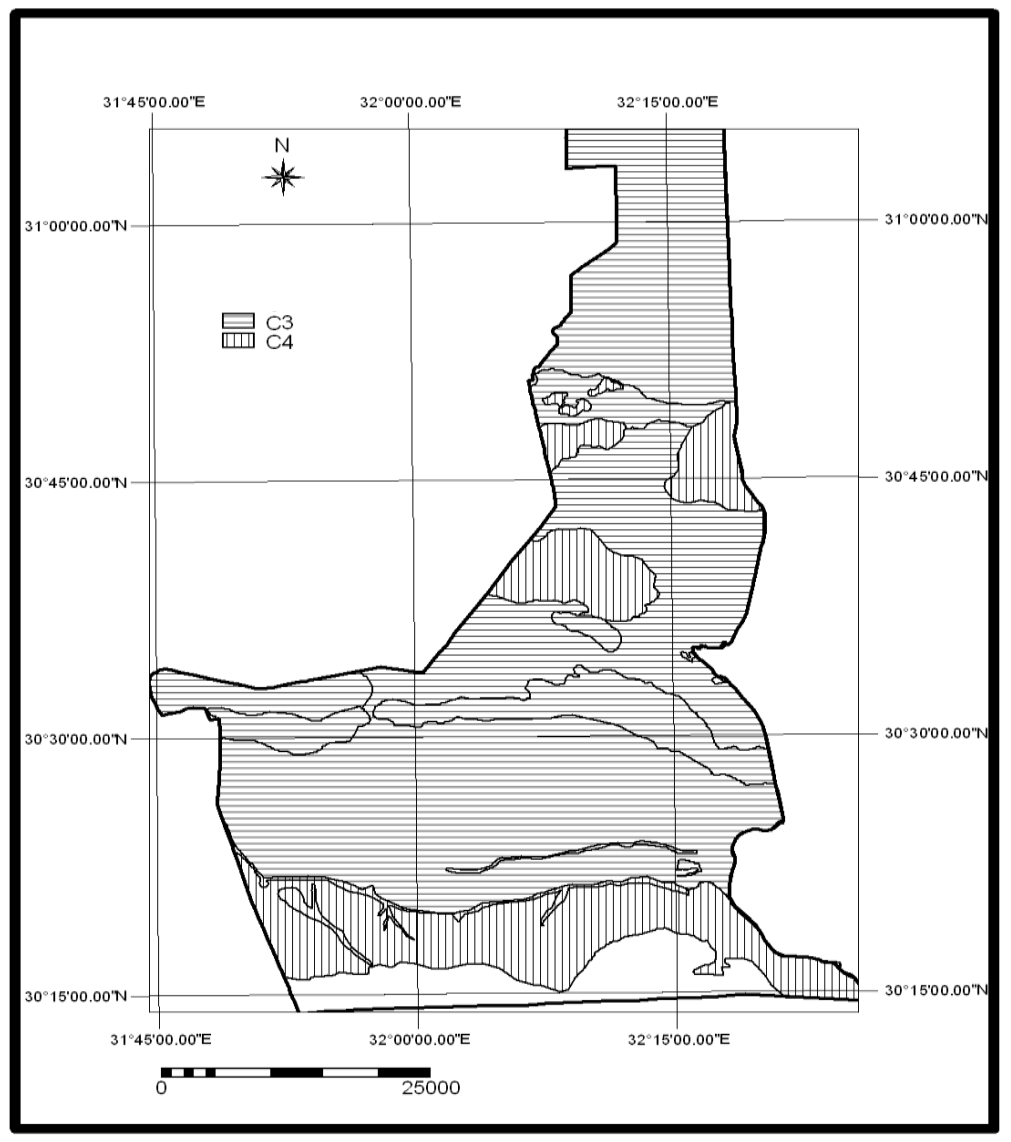

Figure (2): Capability map of the study area

\section{The obtained results revealed the following:}

\section{Land capability C3 (Fair)}

This capability class included most of the soils of the study area where it covered almost $72 \%$ of the total area under investigation. The soils of this class had several limitations such as clay content ( $\mathrm{t}$ ), cation exchange capacity (CEC) and alkalinity (al). The number of limitations varied between one and five limiting factors. These limiting factors reduce the choices of the possible crops for cultivation.

As these soils become under cultivation, careful management and conservation practices are required to improve and conserve their properties.

Each distinctive kind of soil in this capability class has one or more alternative combinations of uses and practices, but the number of practical alternatives is less than that for the soils of higher capability classes (Sys et al, 1991). 
However, some of these limitations can be readily corrected such as cation exchange capacity. It is commonly necessary to supply organic material to such soils to improve both water and nutrient retention.

Land capability C4 (Poor)

The soils that belonged to $\mathrm{C} 4$ occupied about $21 \%$ of the entire area of the governorate. These soils had several limitations but severer than those of C3. The limitations of the soils in $\mathrm{C} 4$ were the same as for $\mathrm{C} 3$, but the number of limiting factors was different where, it varied between three and five limiting factors.

The restriction in use for the soils of class $\mathrm{C} 4$ is greater than those of class 3 and the choices of crops to be cultivated, consequently, are limited. More careful management and conservation practices are essential for such soils. These practices are to be applied more frequently and intensively than those on soils of $\mathrm{C} 3$.

Land Suitability Classification

The land suitability indices of the selected eight crops had been calculated and suitability classes were defined (Table.3). A land suitability map of each crop was produced to perform the spatial distribution of the various suitability classes over the area under investigation (Figs. 3 and 4).

\section{Land suitability for cereal crops}

The results reveled that nearly $27.5 \%$ of the soils in the studied area belonged to suitable (S1), about $70 \%$ were moderately suitable (S2) and almost $2.5 \%$ were marginally suitable S3 for wheat and barely cultivation. The limiting factors are either texture for (S2) or salinity for S3. It is worth to mention that (S1) included the heavy textured soils, (S2) class included light textured soils and (S3) class included the saline gypsic soils where the total soluble salts reduce the yield.

The studied soils, however, were marginally suitable (S3) in about $25 \%$, conditionally suitable (S4) in almost $72.5 \%$ and potentially suitable (NS1) in approximately $2.5 \%$ of the total investigated area for maize production. The limitations for maize were found to be more than those for wheat and barley. They were ESP for (S3), texture, and ESP for (S4) and salinity, and ESP for (NS1).

Sarmadian et al.(2003) got similar results where they showed that qualitative suitability class for land mapping units of the region in current conditions for wheat and barley are often S1 and S2 and for some units (S3) and (N), for cotton and maize they are (S2), (S3) and (N) for some units. These classes can be increased by solving some important problems such as soil fertility limitations.

Nearly $25 \%$ of the soils under investigation were suitable (S1), about $2.5 \%$ marginally suitable (S3) and almost $72.5 \%$ actually unsuitable (NS2) for rice production. The land suitability classification showed that the soil of class (S3) had salinity and texture as limiting factors, while for the soils of class (NS2) texture was the only limitation where they were characterized by sandy texture. 
J. Agric. Sci. Mansoura Univ., 33(11), November, 2008 T3 
Ghabour, T. K. et al.

Wheat

Barely

Maize

Rice

Figure (3): Land suitability for Cereal Crops

8312 
J. Agric. Sci. Mansoura Univ., 33(11), November, 2008

Alfalfa

Faba-bean

Sugar beet

Sunflower

Figure (4): Land suitability for Alfalfa, Faba bean, Sugar beet and Sunflower.Land suitability for alfalfa

8313 
The soils of the region were suitable (S1) in approximately $47.5 \%$, moderately suitable (S2) in almost $50 \%$ and marginally suitable S3 in about $2.5 \%$ of the area for alfalfa. The soils belonged to S2 had light texture limitation and those included in S3 had salinity limitation.

\section{Land suitability for faba bean}

Most of the soils which represented almost $95 \%$ of the area were conditionally suitable (S4) for faba bean whereas, only about $2.5 \%$ were marginally suitable (S3) and $2.5 \%$ were potentially suitable NS1. The limiting factors were texture, and ESP for the soils belonged to (S4) and soil salinity, and ESP and for those under (NS1).

\section{Land suitability for sunflower}

Almost $97.5 \%$ of the soils in the area under investigation were marginally suitable (S3) for sunflower and the rest of the area which represented nearly $2.5 \%$ showed conditionally suitability (S4). Soil texture was the main limitation of the class S3, whereas soil salinity was the main limiting factor for the soils of (S4).

\section{Land suitability for sugar beet}

The soils of about $24.8 \%$ of the area were found to be suitable (S1) for sugar beet, $57.4 \%$ were moderately suitable (S2), $15.2 \%$ were marginally suitable (S3) and $2.6 \%$ were conditionally suitable (S4). Limiting factors varied from soil texture and ESP for the soils of (S2) to soil salinity and ESP for those of (S4).

\section{REFERENCES}

Black, C.A.; Evans, D.D.; White, J.I.; Ensminger, L.E. and Clark, F.E. (1982). Methods of Soil Analysis. Amer. Soc. agronomy. Inc. publisher Madison, Wisconsin, U.S.A.

De Coninck, F. (1978). General Chemistry for Soil Scientists. ITC course, State Univ. of Ghent, Belgium, $146 \mathrm{p}$.

FAO. (1976). A framework for land evaluation. Soils Bull. No. 32, Rome, p. 72.

FAO. (2006). Guidelines for Soil Description. $4^{\text {th }}$ edition. Rome, Italy.

Ghabour, Th. K. (1998a). Land capability classification of Northern Sinai Governorate using GIS. J. Agric. Sci. Mansoura Univ. 23(12): 56895699.

Ghabour, Th. K.; Rahim, I.S. and Wahba, M.M. (2006). A numerical approach to land suitability for wheat cultivation in the north-western coast region of Egypt. Egypt. J. Soil Sci., 46 (4): 343-355.

Meshref, H.A.; Ghabour, Th. K.; Ghali, F.A.; Wahba, M.M. and Shahin, S.A.S. (2008). Soil Mapping with the aid of Remote Sensing Techniques and GIS. J. Agric. Sci. Mansoura Univ. (In press).

Reddy, M.G.R.; Reddy, G.P.O.; Maji, A.K. and Rao, K.N. (2004). Land evaluation for cotton suitability in a part of eastern Maharashtra plateau using remote sensing and GIS. Agropedology, 14(1): 25-31. 
Sarmadian, F.; Moravvej, K.; Mahmoodi, S. and Ebrahimi-Khomami, S.M.R. (2003). An investigation of land suitability evaluation for irrigated crop, using remote sensing and geographical information system techniques in parts of Varamin plain. Iranian Journal of-Agricultural Sciences; 34 (4): 899-912

Shekinah, D.E.; Saha, S.K. and Rahman, R. (2004). Land capability evaluation for land use planning using GIS. J. Indian Soc. of Soil Sci., 52 (3): 232-237.

Sys, C.; Van Ranst, E. and Debuveye, J. (1991). Land Evaluation. Part II, Methods in Land Evaluation. ITC, Univ. of Ghent, Agricultural Publications - No. 7, General Administration for Development Cooperation, Brussels, Belgium.

Van Diepen, C.A. (1982). Evaluating land evaluation. Annual Report, ISM, Wageningen, The Netherlands, pp. 13-28.

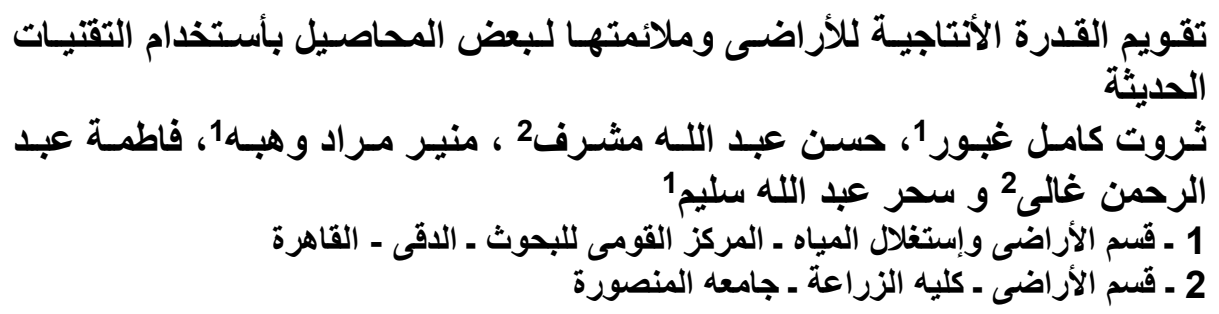

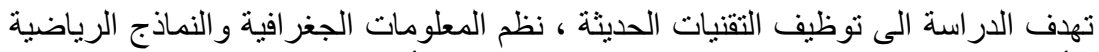

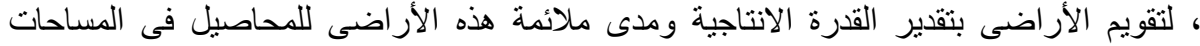

ولقد اختيرت محافظة الاسماعيلية كمنطقة للاراسة حيث غطيث بعدد ستة عشر قطاعا

الكبيرة

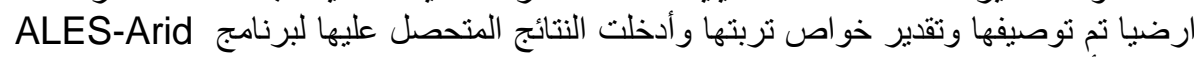

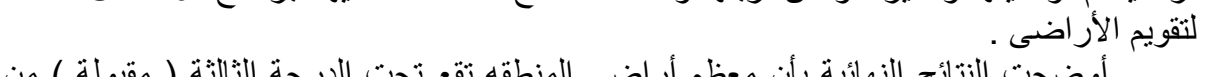

أوضحت النتائج النهائية بأن معظم أراضى المنطقه تقع تحت الدرجة الثالثة ( مقبولة ) من الثنا

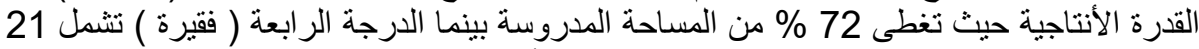

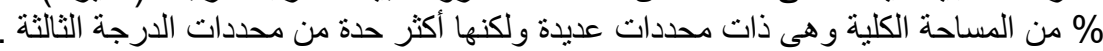

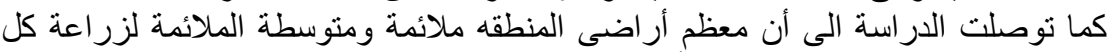

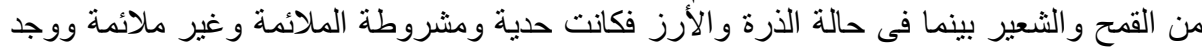

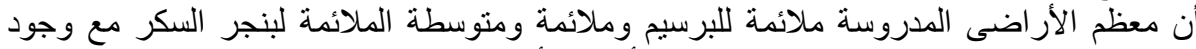

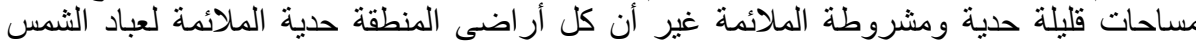

بينما كانت غالبا مشروطة الملائمة للفول البلدى. 
Ghabour, T. K. et al.

8316 
J. Agric. Sci. Mansoura Univ., 33(11): 8305 - 8315, 2008

Table (3): Land suitability classes and their corresponding surface area

\begin{tabular}{|c|c|c|c|c|c|c|c|c|c|c|c|c|}
\hline \multirow[b]{3}{*}{ Crop } & \multicolumn{12}{|c|}{ Land Suitability Classes } \\
\hline & \multicolumn{2}{|l|}{ S1 } & \multicolumn{2}{|l|}{ S2 } & \multicolumn{2}{|c|}{ S3 } & \multicolumn{2}{|l|}{ S4 } & \multicolumn{2}{|c|}{ NS1 } & \multicolumn{2}{|l|}{ NS2 } \\
\hline & $\begin{array}{l}\text { Area in } \\
\text { feddan }\end{array}$ & $\begin{array}{c}\text { Area } \\
\text { in } \\
\%\end{array}$ & $\begin{array}{l}\text { Area in } \\
\text { feddan }\end{array}$ & $\begin{array}{c}\text { Area } \\
\text { in } \\
\%\end{array}$ & $\begin{array}{l}\text { Area in } \\
\text { feddan }\end{array}$ & $\begin{array}{c}\text { Area } \\
\text { in } \\
\%\end{array}$ & $\begin{array}{l}\text { Area in } \\
\text { feddan }\end{array}$ & $\begin{array}{c}\text { Area } \\
\text { in } \\
\%\end{array}$ & $\begin{array}{l}\text { Area in } \\
\text { feddan }\end{array}$ & \begin{tabular}{|c} 
Area \\
in \\
$\%$
\end{tabular} & $\begin{array}{l}\text { Area in } \\
\text { feddan }\end{array}$ & $\begin{array}{c}\text { Area } \\
\text { in } \\
\%\end{array}$ \\
\hline Alfalfa & 294254.50 & 47.46 & 310107.20 & 50.02 & 15619.05 & 2.52 & 0.00 & 0.00 & 0.00 & 0.00 & 0.00 & 0.00 \\
\hline Barely & 170582.07 & 27.51 & 433779.64 & 69.97 & 15621.43 & 2.52 & 0.00 & 0.00 & 0.00 & 0.00 & 0.00 & 0.00 \\
\hline Faba bean & 0.00 & 0.00 & 0.00 & 0.00 & 17252.38 & 2.78 & 587067.46 & 94.70 & 15620.00 & 2.52 & 0.00 & 0.00 \\
\hline Maize & 0.00 & 0.00 & 0.00 & 0.00 & 153686.74 & 24.79 & 450674.97 & 72.69 & 15621.43 & 2.52 & 0.00 & 0.00 \\
\hline Rice & 153686.74 & 24.79 & 0.00 & 0.00 & 15619.05 & 2.52 & 0.00 & 0.00 & 0.00 & 0.00 & 450674.97 & 72.69 \\
\hline Sugar beet & 153686.74 & 24.78 & 356277.05 & 57.47 & 94400.00 & 15.23 & 15620.00 & 2.52 & 0.00 & 0.00 & 0.00 & 0.00 \\
\hline Sunflower & 0.00 & 0.00 & 0.00 & 0.00 & 604361.90 & 97.48 & 15620.00 & 2.52 & 0.00 & 0.00 & 0.00 & 0.00 \\
\hline Wheat & 167431.25 & 27.01 & 436930.46 & 70.47 & 15619.05 & 2.52 & 0.00 & 0.00 & 0.00 & 0.00 & 0.00 & 0.00 \\
\hline $\begin{array}{l}\text { The rocky ar } \\
\text { Total area = } \\
\text { S1= Suitable } \\
\text { S2= Moderat } \\
\text { S3= Margina } \\
\text { S4= Conditio } \\
\text { NS1 = Potent } \\
\text { NS2= Actual }\end{array}$ & $\begin{array}{l}\text { a = } 195.34 \text { km } \\
2799.26 \text { km}^{2} \\
\text { ly Suitable } \\
\text { y Suitable } \\
\text { ally Suitable } \\
\text { ally Suitable } \\
\text { Unsuitable }\end{array}$ & & & & & & & & & & & \\
\hline
\end{tabular}


J. Agric. Sci. Mansoura Univ., 33(11): 8305 - 8315, 2008 